\title{
The Metabolism of Sulphonamides
}

\section{THE RELATION OF THE METABOLIC FATE OF AMBAMIDE (MARFANIL) AND V 335 TO THEIR LACK OF SYSTEMIC ANTIBACTERIAL ACTIVITY}

\section{By R. L. HARTLES AND R. T. WILLIAMS, Department of Biochemistry, University of Liverpool}

\author{
(Received 14 November 1946)
}

$p$-Aminomethylbenzenesulphonamide (I) was first described by Miller, Sprague, Kissinger \& McBurney (1940), and is used in therapy as its hydrochloride, Ambamide (formerly Marfanil). Its antibacterial properties were studied by Klarer (1941) who found it to be less active than sulphanilamide against streptococci, but more active against anaerobic bacteria (cf. Schoop \& Stoltz, 1941 ; Hamre, Walker, Dunham, van Dyke \& Rake, 1944 ; Lawrence, 1945). It differs chemically from sulphanilamide (II) in that its amino group is aliphatic. Unlike sulphanilamide, its antibacterial action is not inhibited by $p$-aminobenzoic acid and is immediate, showing no latent

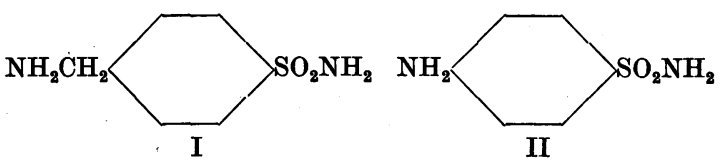

period as do sulphonamides possessing an aromatic amino group (Jensen, Schmith \& Brandt, 1942). Furthermore, it is not inhibited by the analogous $p$ aminomethylbenzoic acid, nor by aneurin or nicotinic acid (Schmith, 1943).

There is, however, a considerable difference between its in vivo and its in vitro activity. When given orally or intraperitoneally the drug affords no protection to mice infected with $\mathrm{Cl}$. welchii. It gives complete protection when injected intramuscularly at the site of infection, but none if the injection is remote from the site of infection (Evans, Fuller \& Walker, 1944; Siebenmann \& Plummer, 1945). Ambamide has been used successfully for the treatment of surface wounds (Mitchell, Rees \& Robinson, 1944) where sulphanilamide would be inhibited by pus and necrotic tissue. When used systemically the drug is of little value.

A study of the metabolism of $p$-methylsulphonylbenzylamine hydrochloride (V 335) (III) has also been included in this paper, for its antibacterial properties are similar to those of Ambamide (Evans et al. 1944).

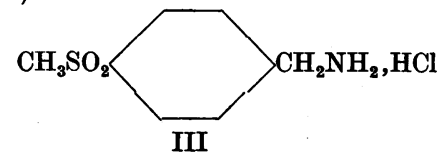

In the present work it will be shown that the systemic inactivity of Ambamide and of V 335 is due to their rapid transformation in the body into antibacterially inactive metabolites. A clue to the mechanism of the inactivation of these drugs was provided by the observations of Beyer \& Govier (1945) and of Blaschko \& Duthie (1945), that Ambamide and V 335 were substrates for amine oxidase.

\section{METHODS AND RESULTS}

\section{Experiments with Ambamide}

Isolation of p-carboxybenzeriesulphonamide from Ambamide urine. A rabbit was given, by stomach tube, $2.06 \mathrm{~g}$. of Ambamide (m.p. $261^{\circ}$ )* dissolved in water. The urine (170 ml.; alkaline to litmus) was collected during $24 \mathrm{hr}$., filtered through glass wool and centrifuged. It was treated with $\frac{1}{10}$ vol. of conc. $\mathrm{HCl}$ and a copious crystalline precipitate separated. After an hour at $0^{\circ}$, the precipitate was filtered at the pump, dried at $100^{\circ}$ and weighed. The product (m.p. $280-285^{\circ} ; 2.15$ g.) was recrystallized (charcoal) twice from aqueous ethanol and $p$-carboxybenzenesulphonamide was obtained as clusters of long white rods, m.p. and mixed m.p. 295-296 ${ }^{\circ}$. (Found: C, $42.1 ; \mathrm{H}, 3.55 ; \mathrm{N}, 6.8 ; \mathrm{S}, 15.4 \%$; equiv. by titration, 200.7 : calc. for $\mathrm{C}_{7} \mathrm{H}_{7} \mathrm{O}_{4} \mathrm{NS}$ : $\mathrm{C}, 41 \cdot 8 ; \mathrm{H}, 3 \cdot 5 ; \mathrm{N}, 7 \cdot 0$; $\mathrm{S}, 15.9 \%$; equiv. 201.2.) The ultra-violet absorption spectrum of $p$-carboxybenzenesulphonamide in ethanol showed maxima at $\lambda_{\max } .234 \mathrm{~m} \mu\left(\epsilon_{\max }\right.$. $15,960)$, at $\lambda_{\max } 277 \mathrm{~m} \mu\left(\epsilon_{\max } .1474\right)$ and at $\lambda_{\max }$. $285.5 \mathrm{~m} \mu\left(\epsilon_{\max } 1228\right)$; and minima at $\lambda_{\min } .267 \mathrm{~m} \mu$ $\left(\epsilon_{\min } .1105\right)$ and $\lambda_{\min } .283 \mathrm{~m} \mu\left(\epsilon_{\min }\right.$. 1105). Synthetic $p$-carboxybenzenesulphonamide, m.p. $296^{\circ}$, was prepared by oxidation of $p$-toluenesulphonamide with alkaline permanganate according to Remsen \& Palmer (1882).

Quantitative determination of the p-carboxybenzenesulphonamide excreted. Single animals were fed Ambamide by stomach tube. The urine was collected after $24 \mathrm{hr}$. and after $48 \mathrm{hr}$. It was found in all animals that the excretion of carboxybenzenesulphonamide was complete within $24 \mathrm{hr}$. Each urine was centrifuged and a sample $(50-100 \mathrm{ml}$.) of the

\footnotetext{
* Melting-points are uncorrected.
} 
clear urine was acidified with $\frac{1}{10}$ vol. of conc. $\mathrm{HCl}$. The acidified urine was kept at $0^{\circ}$ for an hour and then the precipitated sulphonamide was collected in a weighed Gooch crucible. The whole was dried at $100^{\circ}$ and weighed. The filtrate from the precipitate was now extracted with ether for $6 \mathrm{hr}$. in a continuous extractor. The ethereal extract was evaporated and the residue dissolved in a little dilute sodium hydroxide solution, treated with charcoal and filtered. The filtrate was acidified with conc. $\mathrm{HCl}$ as before and the precipitate filtered and weighed.

The relative amounts of .carboxybenzenesulphonamide obtained by acid precipitation and by ether extraction varied considerably. In some cases the larger amount was obtained by acid precipitation whereas in others it was obtained by ether extraction (see Table 1).
The experiment was repeated, but this time the dry residue was extracted with ethanol. The above colour reaction was performed on the ethanolic extract without positive results.

It was concluded therefore, that, in rabbits, no orally administered Ambamide in doses of $500 \mathrm{mg}$./ kg. was excreted unchanged.

Attempted detection of a glycine conjugate. A possible but unlikely metabolite of Ambamide is $p$ sulphonamidohippuric acid. $18 \mathrm{~g}$. of Ambamide were therefore fed to rabbits and the $24 \mathrm{hr}$. urine $(640 \mathrm{ml}$.) acidified with $\mathrm{HCl}$. The precipitated $p$ carboxybenzenesulphonamide was fractionated from water, but no trace of a glycine conjugate was detected.

The urinary filtrate was now brought to $\mathrm{pH} 7$ with $\mathrm{Na}_{2} \mathrm{CO}_{3}$ and treated with excess saturated normal lead acetate solution. The precipitate was removed

Table 1. The output of p-carboxybenzenesulphonamide from rabbits after the oral administration of Ambamide

\begin{tabular}{|c|c|c|c|c|c|c|c|c|c|c|}
\hline \multirow[b]{3}{*}{$\begin{array}{c}\text { Rabbit } \\
\text { no. }\end{array}$} & \multirow[b]{3}{*}{$\begin{array}{l}\text { Wt. } \\
\text { (kg.) }\end{array}$} & \multirow[b]{3}{*}{$\begin{array}{l}\text { Dose } \\
\text { (g.) }\end{array}$} & \multirow[b]{3}{*}{$\begin{array}{c}\text { Dose/kg. } \\
\text { (mg.) }\end{array}$} & \multirow[b]{3}{*}{$\begin{array}{l}\text { Urine vol. } \\
\text { (ml.) }\end{array}$} & \multirow{3}{*}{$\begin{array}{c}\text { Vol. of } \\
\text { sample } \\
\text { analyzed } \\
\text { (ml.) }\end{array}$} & \multicolumn{5}{|c|}{$p$-Carboxybenzenesulphonamide } \\
\hline & & & & & & \multicolumn{2}{|c|}{$\begin{array}{c}\begin{array}{c}\text { Obtained from sample } \\
\text { analyzed (mg.) }\end{array} \\
\text { (maled }\end{array}$} & \multicolumn{3}{|c|}{$\%$ of dose } \\
\hline & & & & & & By pptn. & By extraction & By pp & $\underset{\text { Btraction }}{\text { By }}$ & Total \\
\hline $\begin{array}{l}69 \\
71\end{array}$ & $\begin{array}{l}2 \cdot 7 \\
2 \cdot 55\end{array}$ & $\begin{array}{l}2 \cdot 060 \\
2 \cdot 090\end{array}$ & $\begin{array}{l}768 \\
820\end{array}$ & $\begin{array}{r}90 \\
195\end{array}$ & $\begin{array}{r}50 \\
100\end{array}$ & $\begin{array}{l}738 \cdot 2 \\
357 \cdot 2\end{array}$ & $\begin{array}{r}9 \cdot 3 \\
295 \cdot 9\end{array}$ & $\begin{array}{l}71 \cdot 4 \\
36 \cdot 8\end{array}$ & $\begin{array}{r}0.9 \\
30 \cdot 6\end{array}$ & $\begin{array}{l}72 \cdot 3 \\
67 \cdot 4\end{array}$ \\
\hline $\begin{array}{l}49 \\
50 \\
69 \\
49 \\
50 \\
69\end{array}$ & $\begin{array}{l}2 \cdot 8 \\
3 \cdot 0 \\
2 \cdot 75 \\
2 \cdot 7 \\
2 \cdot 8 \\
2 \cdot 6\end{array}$ & $\begin{array}{l}1 \cdot 396 \\
1 \cdot 515 \\
1 \cdot 375 \\
1 \cdot 446 \\
1 \cdot 427 \\
1 \cdot 490\end{array}$ & $\begin{array}{l}499 \\
505 \\
500 \\
535 \\
510 \\
573\end{array}$ & $\begin{array}{r}104 \\
97 \\
88 \\
160 \\
150 \\
120\end{array}$ & $\begin{array}{r}98 \\
92 \\
84 \\
145 \\
145 \\
115\end{array}$ & $\begin{array}{l}599 \cdot 0 \\
479 \cdot 8 \\
513 \cdot 8 \\
843 \cdot 8 \\
659 \cdot 9 \\
864 \cdot 5\end{array}$ & $\begin{array}{r}396 \cdot 2 \\
160 \cdot 0 \\
180 \cdot 0 \\
95 \cdot 2 \\
115 \cdot 1 \\
82.9\end{array}$ & $\begin{array}{l}50 \cdot 4 \\
37 \cdot 0 \\
43 \cdot 3 \\
71 \cdot 4 \\
53 \cdot 0 \\
67 \cdot 0\end{array}$ & $\begin{array}{r}33 \cdot 2 \\
12 \cdot 3 \\
15 \cdot 2 \\
8 \cdot 0 \\
9 \cdot 2 \\
6 \cdot 4\end{array}$ & $\begin{array}{l}83 \cdot 6 \\
49 \cdot 3 \\
58 \cdot 5 \\
79 \cdot 4 \\
69 \cdot 2 \\
73 \cdot 4\end{array}$ \\
\hline $\begin{array}{l}91 \\
92 \\
93 \\
94 \\
95 \\
96\end{array}$ & $\begin{array}{l}2 \cdot 45 \\
2 \cdot 3 \\
2 \cdot 5 \\
2 \cdot 1 \\
1.9 \\
1.9\end{array}$ & $\begin{array}{l}0.754 \\
0.739 \\
0.776 \\
0.585 \\
0.557 \\
0.538\end{array}$ & $\begin{array}{r}308 \\
321 \\
310 \\
280 \\
293 \\
283\end{array}$ & $\begin{array}{l}100 \\
110 \\
110 \\
100 \\
100 \\
110\end{array}$ & $\begin{array}{r}80 \\
100 \\
100 \\
90 \\
90 \\
100\end{array}$ & $\begin{array}{c}174 \cdot 2 \\
278 \cdot 4 \\
292 \cdot 5 \\
31 \cdot 2 \\
0 \\
0\end{array}$ & $\begin{array}{r}118 \cdot 1 \\
114 \cdot 2 \\
79 \cdot 0 \\
248 \cdot 8 \\
181 \cdot 4 \\
194 \cdot 4\end{array}$ & $\begin{array}{c}32 \cdot 0 \\
45 \cdot 9 \\
45 \cdot 9 \\
6 \cdot 6 \\
0 \\
0\end{array}$ & $\begin{array}{l}21 \cdot 7 \\
18 \cdot 8 \\
12 \cdot 4 \\
52 \cdot 4 \\
40 \cdot 1 \\
44 \cdot 0\end{array}$ & $\begin{array}{l}53 \cdot 7 \\
64 \cdot 7 \\
58 \cdot 3 \\
59 \cdot 0 \\
40 \cdot 1 \\
44 \cdot 0\end{array}$ \\
\hline
\end{tabular}

$A$ colour reaction for Ambanide and the attempted detection of the free drug in urine. Equimolecular proportions of free $p$-aminomethylbenzenesulphonamide (m.p. $153^{\circ}$, prepared from Ambamide, cf. Klarer, 1941) and 2:4-dinitrobenzaldehyde were heated for 5-10 min. in ethanolic solution containing a little glacial acetic acid. A yellow solution was obtained.(probably containing a Schiff's base) which turned a deep purple when made alkaline with $\mathrm{NaOH}$. The colour faded to brownish in about $10 \mathrm{~min}$.

Six rabbits received collectively $6.5 \mathrm{~g}$. of Ambamide orally. A volume of $500 \mathrm{ml}$. of the $24 \mathrm{hr}$. urine (1635 ml.) was taken to dryness under reduced pressure. The dry residue was extracted with $25 \mathrm{ml}$. $2 \mathrm{~N}-\mathrm{NaOH}$, and the alkaline solution extracted with ether. On evaporation of the ether, the residue that remained was negligible. by filtration and the filtrate treated with basic lead acetate at $\mathrm{pH}$ 9. The precipitate was collected, washed and the lead removed by $\mathrm{H}_{2} \mathrm{~S}$. The filtrate from the lead sulphide was taken to dryness. From the residue a little $p$-carboxybenzenesulphonamide was isolated but no trace of its glycine conjugate.

Ethereal sulphate output after feeding Ambamide. The ethereal sulphate output after Ambamide, was determined in rabbits carefully maintained on a constant diet. The urine was analyzed for total and inorganic sulphate by the Folin gravimetric method, the normal output of ethereal sulphate being calculated as described in earlier papers (e.g. Williams, 1938; Dobson \& Williams, 1946). The results are given in Table 2.

The accuracy of estimating a rise in ethereal sulphate by this method is about $\pm 5 \%$ and therefore 
Table 2. Ethereal sulphate output from rabbits receiving Ambamide

\begin{tabular}{|c|c|c|c|c|c|c|}
\hline \multirow[b]{2}{*}{$\begin{array}{c}\text { Rabbit } \\
\text { no. }\end{array}$} & \multirow[b]{2}{*}{$\begin{array}{c}\text { Dose } \\
\text { (mg./kg.) }\end{array}$} & \multicolumn{3}{|c|}{ Ethereal sulphate (mg. $\mathrm{SO}_{3}$ ) } & \multicolumn{2}{|c|}{ Ambamide equivalent } \\
\hline & & $\begin{array}{l}\text { Mean normal } \\
\text { value }\end{array}$ & $\begin{array}{c}\text { After } \\
\text { Ambamide }\end{array}$ & $\underset{\text { rise }}{\text { Apparent }}$ & (mg.) & (\% of dose) \\
\hline $\begin{array}{l}48 \\
49 \\
91 \\
92 \\
93\end{array}$ & $\begin{array}{l}250 \\
250 \\
250 \\
250 \\
250\end{array}$ & $\begin{array}{l}27 \cdot 5 \\
28 \cdot 6 \\
24 \cdot 6 \\
22 \cdot 9 \\
23 \cdot 6\end{array}$ & $\begin{array}{l}38 \cdot 4 \\
50 \cdot 7 \\
40 \cdot 0 \\
15 \cdot 1 \\
53 \cdot 2\end{array}$ & $\begin{array}{r}10 \cdot 9 \\
22 \cdot 1 \\
15 \cdot 4 \\
-7 \cdot 8 \\
29 \cdot 6\end{array}$ & $\begin{array}{c}30 \cdot 3 \\
61 \cdot 4 \\
42 \cdot 8 \\
\overline{82 \cdot 3}\end{array}$ & $\begin{array}{c}3 \cdot 9 \\
8 \cdot 6 \\
7 \cdot 4 \\
0 \\
13 \cdot 2\end{array}$ \\
\hline $\begin{array}{l}\mathbf{9 1} \\
92 \\
\mathbf{9 3} \\
\mathbf{9 4} \\
\mathbf{9 5} \\
\mathbf{9 6} \\
\mathbf{7 3} \\
\mathbf{7 4}\end{array}$ & $\begin{array}{l}500 \\
500 \\
500 \\
500 \\
500 \\
500 \\
500 \\
500\end{array}$ & $\begin{array}{r}24 \cdot 2 \\
19 \cdot 7 \\
23 \cdot 5 \\
23 \cdot 0 \\
17 \cdot 5 \\
19 \cdot 9 \\
24 \cdot 0 \\
13 \cdot 0\end{array}$ & $\begin{array}{l}31 \cdot 9 \\
23 \cdot 2 \\
44 \cdot 7 \\
27 \cdot 8 \\
14 \cdot 2 \\
31 \cdot 9 \\
47 \cdot 0 \\
34 \cdot 0\end{array}$ & $\begin{array}{r}7 \cdot 7 \\
3 \cdot 5 \\
21 \cdot 2 \\
5 \cdot 8 \\
-3 \cdot 3 \\
12 \cdot 0 \\
23 \cdot 0 \\
21 \cdot 5\end{array}$ & $\begin{array}{r}21 \cdot 4 \\
9 \cdot 7 \\
58 \cdot 9 \\
16 \cdot 1 \\
- \\
\mathbf{3 3 \cdot 4} \\
\mathbf{6 3 \cdot 9} \\
\mathbf{5 9 \cdot 8}\end{array}$ & $\begin{array}{l}1 \cdot 8 \\
0 \cdot 9 \\
4 \cdot 6 \\
1 \cdot 4 \\
0 \\
3 \cdot 5 \\
5 \cdot 0 \\
4 \cdot 7\end{array}$ \\
\hline
\end{tabular}

rises in ethereal sulphate of $5 \%$ or less are not significant. In Table 2, the figure of $5 \%$ is exceeded in three experiments at a dose level of $250 \mathrm{mg} . / \mathrm{kg}$., but never at the higher dose of $500 \mathrm{mg} . / \mathrm{kg}$. These figures, therefore, indicate a possibility but not a probability that Ambamide has undergone a nuclear oxidation. Attempts were therefore made to check this by testing Ambamide urine for possible nuclear oxidation products.

\section{Attempts to detect nuclear oxidation products of Ambamide}

If Ambamide undergoes nuclear oxidation in vivo, then it is likely to be oxidized in a position oxtho to the aminomethyl group, the final product of metabolism being 3-hydroxy-4-carboxybenzenesulphonamide, thus: (a) Ethereal sulphate output after p-carboxybenzenesulphonamide. This was determined as for Ambamide. The results are given in Table 3.

Table 3 shows that $p$-carboxybenzenesulphonamide does not produce an increased ethereal sulphate output. The two figures of 6.6 and 6.3 are probably within the range of experimental error of the analytical method.

(b) The detection of 3-hydroxy-4-carboxybenzenesulphonamide in urine. 3-Hydroxy-4-carboxybenzenesulphonamide, m.p. $231^{\circ}$, was prepared essentially according to Walker (1897) (cf. also Bromwell, 1897). (The ultra-violet absorption spectrum of this compound in ethanol showed maxima at $237.5 \mathrm{~m} \mu\left(\epsilon_{\max } .8720\right)$ and $303.5 \mathrm{~m} \mu$ $\left(\epsilon_{\max } .3074\right)$ and minima at $226 \mathrm{~m} \mu\left(\epsilon_{\max } 6365\right)$ and $\left.262 \mathrm{~m} \mu\left(\epsilon_{\max } 240\right)\right)$. This compound gives a very intense red colour with $2 \%$ aqueous ferric chloride

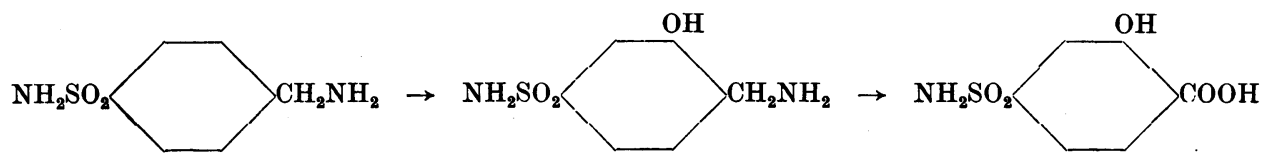

Nuclear oxidation after transformation to $p$ carboxybenzenesulphonamide is unlikely, for compounds carrying two acidic groups attached to the aromatic ring are usually rapidly excreted as such. This point was checked by measurement of the ethereal sulphate output after feeding $p$-carboxybenzenesulphonamide. and can be detected in small amounts in urine by this colour test. The compound was fed orally to rabbits in doses which could be expected to occur in the urine of rabbits receiving Ambamide, if the latter were converted to it to the extent of $5 \%$ at a dose level of $350 \mathrm{mg} . / \mathrm{kg}$. Two rabbits were, therefore, fed 47.5 and $67 \mathrm{mg}$. respectively of hydroxycarboxy.

Table 3. Ethereal sulphate output from the rabbit after feeding p-carboxybenzenesulphonamide

\begin{tabular}{|c|c|c|c|c|c|c|}
\hline \multirow[b]{2}{*}{$\begin{array}{c}\text { Rabbit } \\
\text { no. }\end{array}$} & \multirow[b]{2}{*}{$\begin{array}{c}\text { Dose } \\
(\mathrm{mg} \cdot / \mathrm{kg} .)\end{array}$} & \multicolumn{3}{|c|}{ Ethereal sulphate output (mg. $\mathrm{SO}_{3}$ ) } & \multicolumn{2}{|c|}{$\begin{array}{l}p \text {-Carboxybenzenesulphonamide } \\
\text { equivalent to rise }\end{array}$} \\
\hline & & $\begin{array}{l}\text { Mean normal } \\
\text { value }\end{array}$ & $\begin{array}{l}\text { After the } \\
\text { sulphonamide }\end{array}$ & $\underset{\text { rise }}{\text { Apparent }}$ & (mg.) & $(\%$ of dose $)$ \\
\hline $\begin{array}{l}74 \\
94 \\
95 \\
96\end{array}$ & $\begin{array}{l}250 \\
250 \\
250 \\
250\end{array}$ & $\begin{array}{l}23 \cdot 5 \\
20 \cdot 9 \\
16 \cdot 9 \\
22 \cdot 3\end{array}$ & $\begin{array}{l}18 \cdot 0 \\
35 \cdot 1 \\
12 \cdot 7 \\
34 \cdot 1\end{array}$ & $\begin{array}{r}-5 \cdot 5 \\
14 \cdot 2 \\
-4 \cdot 2 \\
11 \cdot 8\end{array}$ & $\begin{array}{l}\overline{35 \cdot 5} \\
\overline{29 \cdot 5}\end{array}$ & $\begin{array}{l}0 \\
6 \cdot 6 \\
0 \\
6 \cdot 3\end{array}$ \\
\hline $\begin{array}{l}73 \\
75\end{array}$ & $\begin{array}{l}500 \\
500\end{array}$ & $\begin{array}{l}41 \cdot 5 \\
25 \cdot 4\end{array}$ & $\begin{array}{l}35 \cdot 1 \\
25 \cdot 6\end{array}$ & $\begin{array}{r}-6.4 \\
0.2\end{array}$ & - & $\begin{array}{l}0 \\
0\end{array}$ \\
\hline
\end{tabular}


benzenesulphonamide. Three hours later the urine of each rabbit was collected. Samples $(2 \mathrm{ml}$.) of the urines were acidified with a few drops of conc. $\mathrm{HCl}$ and then shaken up with ether. The ether layer was poured into an equal volume of water. The addition of a few drops of $2 \%$ ferric chloride produced an intense red colour in the aqueous layer, which indicates that hydroxycarboxybenzenesulphonamide had been rapidly excreted in the free state.

(c) Attempted detection of 3-hydroxy-4-carboxybenzenesulphonamide in Ambamide urine. A total of $14 \mathrm{~g}$. of Ambamide was administered orally to seven rabbits (dose c. $800 \mathrm{mg} . / \mathrm{kg}$.). The urine $(800 \mathrm{ml}$.) collected during $24 \mathrm{hr}$. was pooled and clarified by centrifuging. A quantity of $760 \mathrm{ml}$. was acidified with $\frac{1}{10}$ vol. of conc. $\mathrm{HCl}$, and the precipitate gave no ferric chloride reaction when dissolved in water. The filtrate was now refluxed for $2 \mathrm{hr}$. to hydrolyze conjugated phenols. The mixture was cooled and extracted with ether for $12 \mathrm{hr}$. in a continuous extractor. Evaporation of the ether yielded a residue $(2.5 \mathrm{~g}$.) which gave no colour test for 3-hydroxy-4-carboxybenzenesulphonamide, but yielded on recrystallization $2 \cdot 2 \mathrm{~g}$. of $p$-carboxybenzenesulphonamide, m.p. $294^{\circ}$.

\section{Attempted detection of acetylation of Ambamide in vivo}

(a) Preparation of p-acetamidomethylbenzenesulphonamide. Ambamide (5 g.) was dissolved in $20 \mathrm{ml}$. water and $8 \mathrm{~g}$. of $\mathrm{Na}_{2} \mathrm{CO}_{3}$ in $10 \mathrm{ml}$. warm water added. To the mixture $5 \mathrm{ml}$. acetic anhydride were added, the whole shaken for about $5 \mathrm{~min}$. and then kept at room temperature for $2 \mathrm{hr}$. The mixture was acidified with dilute $\mathrm{HCl}$ and the acetyl compound separated as white needles. Recrystallization from hot water gave 4 g., m.p. $177^{\circ}$ (Klarer (1941) gives m.p. $177^{\circ}$ ).

(b) Fate of the acetyl compound in the rabbit. The acetyl compound ( $1.65 \mathrm{~g}$.) was fed orally to a rabbit (dose $666 \mathrm{mg}$. $/ \mathrm{kg}$.) and the urine collected for $24 \mathrm{hr}$. The urine was reduced to $30 \mathrm{ml}$. under diminished pressure and acidified with $\mathrm{HCl}$. A crystalline precipitate $(0.25 \mathrm{~g}$.) separated. This was recrystallized twice (charcoal) from hot water and identified as $p$-acetamidomethylbenzenesulphonamide, m.p. and mixed m.p. $177^{\circ}$. No trace of $p$-carboxybenzenesulphonamide was detected by acid precipitation or ether extraction. No phenolic compound was detected in an ether extract of the hydrolyzed urine.

(c) The absence- of p-acetamidomethylbenzenesulphonamide from Ambamide urine. In no case was an acetyl compound detected in Ambamide urine in the precipitate obtained by acidification or in the ethereal extract of the acidified urine.

Glucuronide formation. No quantitative estimations of the glucuronic acid output after feeding Ambamide were carried out, for qualitative tests indicated that no significant increase in glucuronic acid occurred.

\section{Experiments with V 335}

Isolation of p-methylsulphonylbenzoic acid from $V 335$ urine. Two rabbits were each given by stomach tube $1.5 \mathrm{~g}$. V 335 (m.p. $265^{\circ}$ ) in water. The urine $(240 \mathrm{ml}$.) was collected after $24 \mathrm{hr}$. and centrifuged. Conc. $\mathrm{HCl}(24 \mathrm{ml}$.) was added to the clear urine and a crystalline precipitate appeared immediately. After the acidified urine had stood a short while, the pale buff precipitate was filtered off and dried (m.p. $262^{\circ}$ ). It was twice recrystallized (charcoal) from aqueous ethanol, forming a mixture of white rods and plates; m.p. and mixed m.p. with synthetic $p$-methylsulphonylbenzoic acid (see below), $267^{\circ}$. Found: $\mathrm{C}, 47 \cdot 9 ; \mathrm{H}, 4 \cdot 3 ; \mathrm{S}, 16 \cdot 1 . \mathrm{C}_{8} \mathrm{H}_{8} \mathrm{O}_{4} \mathrm{~S}$ requires $\mathrm{C}, 48 \cdot 0 ; \mathrm{H}, 4 \cdot 0 ; \mathrm{S}, 16 \%$.

Synthesis of p-methylsulphonylbenzoic acid. $p$ Toluenesulphonyl chloride (British Drug Houses Ltd.) was reduced to $p$-toluenesulphinic acid (m.p. $\mathbf{8 4}^{\circ}$ ) with zinc dust in ether and water (Ullmann \& Pasdermadjian, 1901). The acid was methylated with dimethyl sulphate and $\mathrm{KOH}$ yielding $p$-methylsulphonyltoluene (m.p. $85^{\circ}$ ) (cf. Otto, 1885).

$p$-Methylsulphonyltoluene $(0.8 \mathrm{~g}$.) was refluxed for $2 \mathrm{hr}$. with $3 \mathrm{~g}$. $\mathrm{KMnO}_{4}$ in $100 \mathrm{ml}$. water. The excess $\mathrm{KMnO}_{4}$ was destroyed with ethanol and the solution filtered from the precipitate of oxides of manganese.

Table 4. The output of p-methylsulphonylbenzoic acid by rabbits after oral administration of V 335

\begin{tabular}{|c|c|c|c|c|c|c|c|c|c|}
\hline \multirow[b]{3}{*}{$\begin{array}{c}\text { Rabbit } \\
\text { no. }\end{array}$} & \multirow[b]{3}{*}{$\begin{array}{l}\text { Wt. } \\
\text { (kg.) }\end{array}$} & \multirow[b]{3}{*}{$\begin{array}{c}\text { Dose } \\
\text { (mg./kg.) }\end{array}$} & \multirow{3}{*}{$\begin{array}{l}\text { Urine } \\
\text { vol. } \\
\text { (ml.) }\end{array}$} & \multirow{3}{*}{$\begin{array}{c}\text { Sample } \\
\text { analyzed } \\
\text { vol. } \\
\text { (ml.) }\end{array}$} & \multicolumn{5}{|c|}{$p$-Methylsulphonylbenzoic acid } \\
\hline & & & & & \multicolumn{2}{|c|}{ In sample (mg.) } & \multicolumn{3}{|c|}{$\%$ of dose } \\
\hline & & & & & $\begin{array}{c}\text { By } \\
\text { pptn. }\end{array}$ & $\underset{\text { extraction }}{\mathrm{By}}$ & $\begin{array}{c}\text { By } \\
\text { pptn. }\end{array}$ & $\underset{\text { extraction }}{\text { By }}$ & Total \\
\hline $\begin{array}{l}94 \\
95\end{array}$ & $\begin{array}{l}2 \cdot 3 \\
2 \cdot 15\end{array}$ & $\begin{array}{l}643 \\
692\end{array}$ & $\begin{array}{l}120 \\
118\end{array}$ & $\begin{array}{l}100 \\
100\end{array}$ & $\begin{array}{l}985 \cdot 8 \\
949 \cdot 6\end{array}$ & $\therefore$ - & $\begin{array}{l}88 \cdot 6 \\
82 \cdot 8\end{array}$ & - & - \\
\hline $\begin{array}{l}93 \\
95 \\
96\end{array}$ & $\begin{array}{l}2 \cdot 1 \\
1 \cdot 9 \\
2 \cdot 05\end{array}$ & $\begin{array}{l}546 \\
558 \\
543\end{array}$ & $\begin{array}{l}100 \\
255 \\
130\end{array}$ & $\begin{array}{r}50 \\
100 \\
100\end{array}$ & $\begin{array}{l}387 \cdot 4 \\
243 \cdot 9 \\
609 \cdot 3\end{array}$ & $\begin{array}{l}36 \cdot 6 \\
62 \cdot 6 \\
48 \cdot 5\end{array}$ & $\begin{array}{l}74 \cdot 6 \\
65 \cdot 1 \\
78 \cdot 6\end{array}$ & $\begin{array}{r}7 \cdot 1 \\
16 \cdot 7 \\
6 \cdot 2\end{array}$ & $\begin{array}{l}81 \cdot 7 \\
81 \cdot 8 \\
84 \cdot 8\end{array}$ \\
\hline $\begin{array}{l}38 \\
49\end{array}$ & $\begin{array}{l}2 \cdot 55 \\
3 \cdot 0\end{array}$ & $\begin{array}{l}452 \\
400\end{array}$ & $\begin{array}{l}120 \\
176\end{array}$ & $\begin{array}{l}100 \\
150\end{array}$ & $\begin{array}{l}697 \cdot 2 \\
721 \cdot 3\end{array}$ & - & $\begin{array}{l}80 \cdot 5 \\
78 \cdot 1\end{array}$ & - & - \\
\hline
\end{tabular}


The filtrate was evaporated to $50 \mathrm{ml}$. and acidified with a little $\mathrm{HCl}$. The precipitated p-methylsulphonylbenzoic acid was recrystallized from hot water, forming a mixture of rods and plates, m.p. $267^{\circ}$ (yield $0 \cdot 4$ g.). (Found: C, $47 \cdot 8 ; \mathrm{H}, 4 \cdot 1$; S, $16 \cdot 1 \%$.)

The same acid can be obtained in poor yield by permanganate oxidation of V 335 itself.

Quantitative determination of p-methylsulphonylbenzoic acid in $V 335$ urine. The determination of this acid was carried out in exactly the same manner as described for $p$-carboxybenzenesulphonamide in Ambamide urine. This acid is much less soluble than $p$-carboxybenzenesulphonamide and therefore its determination in most cases could be carried out by acid precipitation and weighing. The results are given in Table 4.

Ethereal sulphate output after V 335 . The determinations were carried out as for Ambamide. The results are given in Table 5 , which shows that, within the limits of experimental error, V 335 does not cause an increased output of ethereal sulphate. probably by an amine oxidase type of oxidation'. This view was supported by the experiments of Beyer \& Govier (1945) with guinea pig liver homogenates and of Blaschko \& Duthie (1945) with a preparation of amine oxidase from rabbit liver, for it was shown that both Ambamide and V 335 were substrates for amine oxidase.

The present view concerning the mechanism of the action of amine oxidase is that the primary amine is dehydrogenated to an imino compound which reacts spontaneously with water to give ammonia and an aldehyde (Richter, 1937; Pugh \& Quastel, 1937). The aldehyde would then be oxidized by an aldehyde oxidizing enzyme to the corresponding acid. For Ambamide the sequence of reactions to $p$-carboxybenzenesulphonamide would be as follows:

$$
\begin{aligned}
\mathrm{NH}_{2} & \mathrm{SO}_{2} \cdot \mathrm{C}_{6} \mathrm{H}_{4} \cdot \mathrm{CH}_{2} \cdot \mathrm{NH}_{2} \rightarrow \mathrm{NH}_{2} \cdot \mathrm{SO}_{2} \cdot \mathrm{C}_{6} \mathrm{H}_{4} \cdot \mathrm{CH}: \mathrm{NH} \\
& \rightarrow \mathrm{NH}_{2} \cdot \mathrm{SO}_{2} \cdot \mathrm{C}_{6} \mathrm{H}_{4} \cdot \mathrm{CHO} \rightarrow \mathrm{NH}_{2} \cdot \mathrm{SO}_{2} \cdot \mathrm{C}_{6} \mathrm{H}_{4} \cdot \mathrm{COOH} .
\end{aligned}
$$

The only stage detectable in the urine is the final stage, for we have failed to get any positive tests for

\begin{tabular}{|c|c|c|c|c|c|c|}
\hline \multirow[b]{2}{*}{$\begin{array}{c}\text { Rabbit } \\
\text { no. }\end{array}$} & \multirow[b]{2}{*}{$\begin{array}{l}\text { Wt. } \\
\text { (kg.) }\end{array}$} & \multirow[b]{2}{*}{$\begin{array}{c}\text { Dose } \\
\text { (mg./kg.) }\end{array}$} & \multicolumn{4}{|c|}{ Ethereal sulphate output (mg. $\mathrm{SO}_{3}$ ) } \\
\hline & & & $\begin{array}{c}\text { Mean } \\
\text { normal } \\
\text { value }\end{array}$ & $\begin{array}{l}\text { After } \\
\text { V 335 }\end{array}$ & $\underset{\text { rise }}{\text { Apparent }}$ & $\begin{array}{c}\text { Rise of } \\
\text { ethereal sulphate } \\
\text { (\% of dose) }\end{array}$ \\
\hline $\begin{array}{l}91 \\
92 \\
93\end{array}$ & $\begin{array}{l}2 \cdot 3 \\
2 \cdot 2 \\
2 \cdot 3\end{array}$ & $\begin{array}{l}504 \\
495 \\
503\end{array}$ & $\begin{array}{l}23 \cdot 0 \\
25 \cdot 1 \\
22 \cdot 7\end{array}$ & $\begin{array}{r}33 \cdot 2 \\
8 \cdot 0 \\
26 \cdot 3\end{array}$ & $\begin{array}{r}10 \cdot 2 \\
-17 \cdot 1 \\
3 \cdot 6\end{array}$ & $\begin{array}{l}2 \cdot 0 \\
0 \\
0 \cdot 7\end{array}$ \\
\hline
\end{tabular}

Table 5. Ethereal sulphate output from rabbits after $V 335$

\section{Antibacterial properties of metabolites}

Through Dr A. Spinks (Imperial Chemical (Pharmaceuticals) Ltd.) both $p$-carboxybenzenesulphonamide and $p$-methylsulphonylbenzoic acid were tested for antibacterial activity. The first compound had no action on Staph. aureus, Strep. pyogenes or Cl. welchii at a dilution of 1/1000. The second compound was tested against Staph. aureus and Strep. pyogenes and found to have no activity at a dilution of $1 / 1000$.

\section{DISCUSSION}

The present work shows that, in the rabbit, Ambamide and V 335 are rapidly transformed into metabolites which possess no antibacterial action. These results, therefore, provide an explanation of the lack of systemic activity shown by these drugs.

Evans et al. (1944) showed that there was a reduction in the in vitro activity of Ambamide and V 335, when these drugs were tested against bacteria in a medium containing whole blood. The reduction in activity in blood was ascribed 'to breakdown at the sensitive benzylamine group,

$$
\mathrm{CH}_{2}-\mathrm{NH}_{2},
$$

an aldehyde in Ambamide urine. Other work in progress in this laboratory on $p$-hydroxybenzylamine has enabled us to detect the aldehyde stage in the urine.

Our results and those of earlier workers indicate that if Ambamide or V 335 encounter amine oxidase anywhere in the body they will in all probability be dehydrogenated and inactivated. This enzyme occurs principally in the liver and intestines although it also occurs in small amounts in other tissues (Blaschko, Richter \& Schlossmann, 1937; Epps, 1945). It would appear therefore that, when given by the oral route, these drugs would be oxidized during absorption from the gut and any escaping oxidation in the intestinal wall would be oxidized in the liver. Little of the unchanged drug would reach the general circulation. It has been suggested (Richter, 1938; Richter, Lee \& Hill, 1941) that the function of the amine oxidase of the intestine is one of detoxication whereby toxic amines formed in the gut by bacterial action are destroyed. The lack of systemic activity of Ambamide and V 335 is therefore a consequence of this detoxicating function of amine oxidase. If derivatives of these drugs could be prepared in which the amino group is protected by a grouping which is gradually hydrolyzed in vivo 
to the free drugs, then the antibacterial activity of these drugs might be preserved in vivo. With this view in mind, $p$-acetamidomethylbenzenesulphonamide was fed but was found to be largely excreted unchanged.

That Ambamide and V 335 might undergo other changes than oxidation by amine oxidase was also investigated. Although a careful search was made for metabolites other than the carboxylic acids, $p$-carboxybenzenesulphonamide and $p$-methylsulphonylbenzoic acid, none was found. An average of $70 \%$ (highest $84 \%$ ) of the Ambamide fed was recovered as $p$-carboxybenzenesulphonamide when the dose was 500-800 mg. $/ \mathrm{kg}$. but with the lower dose of $300 \mathrm{mg} \cdot / \mathrm{kg}$. the average recovery was only $53 \%$. This difference may be due to incomplete recovery of $p$-carboxybenzenesulphonamide, when it occurs in urine at low concentrations. $p$-Carboxybenzenesulphonamide has previously been isolated from urine by Flaschenträger, Bernhard, Loewenberg \& Schläpfer (1934) who found it to be a metabolite of $p$-toluenesulphonamide in the dog. With V335 an average of $83 \%$ (highest $87 \%$ ) of the dose (400$700 \mathrm{mg}$./kg.) was recovered as $p$-methylsulphonylbenzoic acid which appears to be a new compound although its meta and ortho isomers have been described (Smiles' \& Stewart, 1921 ; Arndt, Kirsch \& Nachtwey, 1926). $p$-Methylsulphonylbenzoic acid is less soluble than $p$-carboxybenzenesulphonamide.

Concerning the mode of action of drugs of this type there is little known. Blaschko \& Duthie (1945) have suggested that the drugs may interfere with enzymic systems which are in some way chemically related to amine oxidase. Evans et al. (1944) have pointed out that they are not inhibited by $p$-aminobenzoic acid and their chemical structures do not permit of reference to any known growth factor for bacteria. However, recently Rogers \& Knight (1946) have found that in protein-free horse muscle extract there is a labile substance (toxigenic factor) which enhances $\alpha$-toxin (lecithinase) formation by $C l$. welchii type A (strain S 107). This toxigenic factor has been partially purified and shown to be of relatively small molecular size. Its toxigenic activity appears to depend on the presence of primary amino groups and it may be of the nature of an amino-sugar. We, therefore, make the suggestion that, since Ambamide and V 335 both contain aliphatic primary amino groups and are particularly active against clostridia, these drugs act by interfering with the utilization by the bacteria of substances containing aliphatic primary amino groups such as the toxigenic factor of Rogers \& Knight.

\section{SUMMARY}

1. The metabolic fate of $p$-aminomethylbenzenesulphonamide hydrochloride (Ambamide) and of $p$ methylsulphonylbenzylamine hydrochloride (V 335) in the rabbit has been studied. Ambamide is rapidly oxidized and excreted in the urine as p-carboxybenzenesulphonamide, which is the only metabolite found. Up to $84 \%$ of the Ambamide could be accounted for as this metabolite.

2. Ambamide does not result in the excretion of an ethereal sulphate, a glycine conjugate or a glucuronide. It does not undergo nuclear oxidation or acetylation.

3. $p$-Carboxybenzenesulphonamide and 3-hydroxy-4-carboxybenzenesulphonamide when fed to rabbits are excreted unchanged.

4. $p$-Acetamidomethylbenzenesulphonamide is excreted unchanged.

5. V 335 is excreted as $p$-methylsulphonylbenzoic acid and no other metabolite is found. Up to $87 \%$ of $\mathrm{V} 335$ can be recovered from the urine as this acid.

6. Neither $p$-carboxybenzenesulphonamide nor $p$-methylsulphonylbenzoic acid have any antibacterial activity.

7. The mechanism of the inactivation of Ambamide and V 335 is discussed.

8. A suggestion is made regarding the mode of antibacterial action of Ambamide and V 335.

The authors wish to thank Messrs R. F. Reed, Ltd., Barking, for generous gifts of Ambamide, V 335 and some of their derivatives. The expenses of this work were in part defrayed by a grant from the Medical Research Council.

\section{REFERENCES}

Arndt, F., Kirsch, A. \& Nachtwey, P. (1926). Ber. dtsch. chem. Ges. 59, 1074.

Beyer, K. H. \& Govier, W. M. (1945). Science, 101, 150.

Blaschko, H. \& Duthie, R. (1945). Biochem. J. 39, 347.

Blaschko, H., Richter, D. \& Schlossmann, H. (1937). Biochem. J. 31, 2187.

Bromwell, W. (1897). Amer. chem. J.19, 561.

Dobson, F. \& Williams, R. T. (1946). Biochem. J. 40, 215.

Epps, H. M. R. (1945). Biochem. J. 39, 37.
Evans, D. G., Fuller, A. T. \& Walker, J. (1944). Lancet, $2,523$.

Flaschenträger, B., Bernhard, K., Loewenberg, C. \& Schläpfer, N. (1934). Hoppe-Seyl. Z. 225, 157.

Hamre, D. M., Walker, H. R., Dunham, W. B., van Dyke, H. B. \& Rake, G. (1944). Proc. Soc. exp. Biol., N.Y., 55, 170.

Jensen, K. A., Schmith, K. \& Brandt, P. (1942). Klin. Wschr. 21, 1042.

Klarer, J. (1941). Klin. Wschr. 20, 1250.

Lawrence, C. A. (1945). J. Bact. 49, 149. 
Miller, E., Sprague, J. M., Kissinger, L. W. \& McBurney, L. F. (1940). J. Amer. chem. Soc. 62, 2099.

Mitchell, G. A. G., Rees, W. S. \& Robinson, P. N. (1944). Lancet, 1, 627.

Otto, R. (1885). Ber. dtsch. chem. Ges. 18, 161.

Pugh, C. E. H. \& Quastel, J. H. (1937). Biochem. J. 31, 2306.

Remsen, J. \& Palmer, C. (1882). Amer. chem. J. 4, 142.

Richter, D. (1937). Biochem. J. 31, 2022.

Richter, D. (1938). Biochem. J. 32, 1763.

Richter, D., Lee, M. H. \& Hill, D. (1941). Biochem. J. 35, 1215.
Rogers, H. J. \& Knight, B. C. J. G. (1946). Biochem. J. 40, 400.

Schmith, K. (1943). Acta path. microbiol. Scand. 20, 563.

Schoop, G. \& Stoltz, A. (1941). Dtsch. tierärztl. Wschr. 49, 153.

Siebenmann, C. O. \& Plummer, H. (1945). J. Pharmacol. 83, 71.

Smiles, S. \& Stewart, J. (1921). J. chem. Soc. 119, 1797.

Ullmann, F. \& Pasdermadjian, G. (1901). Ber. dtsch. chem. Ges. 34, 1151.

Walker, C. (1897). Amer. chem. J. 19, 578.

Williams, R. T. (1938). Biochem. J. 32, 878.

\title{
The Fate of Certain Organic Acids and Amides in the Rabbit
}

\author{
2. $p$-HYDROXYBENZOIC ACID AND ITS AMIDE
}

\author{
By H. G. BRAY, BRENDA E. RYMAN AND W. V. THORPE, Department of Physiology, \\ Medical School, University of Birmingham
}

(Received 22 November 1946)

Continuing our investigation of the fate of the carboxylic acid amide grouping in the rabbit we have studied the metabolism of $p$-hydroxybenzoic acid and its amide. There are several metabolic changes, involving either the hydroxyl or carboxyl group, which these compounds might undergo. In the case of the amide the carboxyl group could be formed by hydrolysis, cf. benzamide (Bray, Neale \& Thorpe, 1946a). The hydroxyl group might be conjugated with either glucuronic or sulphuric acid and the carboxyl group with glucuronic acid or with glycine. It is also possible that a second hydroxyl group may be introduced, as with salicylic acid, which Lutwak-Mann (1943) found to give rise in the rat to gentisic acid (2:5-dihydroxybenzoic acid), and with $p$-hydroxybenzenesulphonamide, $4-5 \%$ of which was shown in this laboratory to be converted to 1:2-dihydroxybenzene-4-sulphonamide in the rabbit (Williams, 1941).

The metabolism of $p$-hydroxybenzoic acid has been studied by several workers, since it is a possible product of the putrefactive action of bacteria in the large intestine on tyrosine. Baumann \& Herter (1877) showed that it caused an increase in ethereal sulphate excretion when administered to dogs. Schotten (1882) found that it gave rise to $p$-hydroxyhippuric acid in man, $16 \%$ of a $26 \mathrm{~g}$. dose being excreted in this form and $35 \%$ unchanged. Quick $(1932 a, b)$ also studied this aspect of its metabolism and isolated from the urine of dogs receiving the acid a diglucuronide of $p$-hydroxybenzoic acid, both available groups being conjugated. Sherwin (1918) and Power \& Sherwin (1927), however, found that in both man and the monkey the acid was excreted largely unchanged. The metabolism of the amide does not appear to have been investigated except in so far as it was included in a study of the sulphate conjugation of various derivatives of phenol by Williams (1938).

In this investigation we have examined quantitatively the excretion of free $p$-hydroxybenzoic acid, and its conjugates with glycine, sulphuric acid and glucuronic acid, the latter as ester or ether glucuronides. The amide has been similarly studied in order to estimate the extent to which the amide group can be hydrolyzed in vivo. We have shown that it is possible to obtain extracts of rabbit liver which are capable of hydrolyzing some aromatic amides, and the effect of nuclear substituents on this reaction is being studied. This work will be reported separately, but reference will be made in this paper to some relevant experiments. Various qualitative aspects of the metabolism of the acid and amide have also been investigated, including the isolation of protocatechuic acid and 4-carbamylphenylglucuronide from the urine of rabbits dosed with the amide. Protocatechuic acid is also present, though in smaller amounts, in the urine of rabbits receiving $p$-hydroxybenzoic acid.

\section{METHODS}

Diet and feeding. These were as described in an earlier paper (Bray et al. 1946a). The rabbits used for some of the qualitative experiments received a diet of rabbit pellets 70 g. per diem (diet no. 18, Bruce \& Parkes, 1946) with water ad libitum. The acid was given by stomach tube as a solution of its sodium salt and the amide similarly, as a suspension in water. Five dose levels were used, viz. 